\title{
Effect of Striga Species on Sorghum (Sorghum Bicolor L Moench) Production and its Integrated Management Approaches
}

\author{
Temesgen Begna* \\ Ethiopian Institute of Agricultural Research, Chiro National Sorghum Research and Training Center, Chiro, \\ Ethiopia
}

*Corresponding Authors: Temesgen Begna, Ethiopian Institute of Agricultural Research, Chiro National Sorghum Research and Training Center, Chiro, Ethiopia

\begin{abstract}
Sorghum is the most widely cultivated cereal crop in the world, particularly in the semi-arid tropical region of the countries and is staple food crop for millions of the food-insecure people. However, number of biotic and abiotic factors are limiting sorghum grain yield. These constraints are: diseases, drought, soil fertility, and pests, notably parasitic weed striga species. Among biotic stress, striga weed species are one of the most biological constraints which cause yield losses and perturb food security and human welfares in the world. Striga is an important parasitic weed causing substantial economic losses in cereal and legume crop production in subSaharan Africa. Striga spps are obligate root-parasitic plants of the major agricultural cereal crops including sorghum, maize and millets in tropical and semi-arid regions of Africa, Middle East, Asia and Australia. Striga can cause severe to complete losses in crop grain yield. Production of cereal crops such as sorghum, maize, rice and millet is threatened by striga species in different parts of the world particularly in semi-arid tropics of Africa. The percentage of crop yield loss due to striga infestations depends on amount of striga seeds in the soil, distribution of rainfall, soil fertility and variety of cereal species grown. Striga species spend most of their life cycle underground and develop above ground for stem formation and flowering. Striga stands for the principal biological constraints of crop production than any other biological pests such as insects, birds, or plant diseases in Sub-Saharan Africa. Sorghum production in world is seriously constrained by both biotic and abiotic stresses. Among the biotic stresses is witchweed (Striga spp.), a noxious parasitic weed causing major damage in cereal crops. However, resistance through reduced germination stimulant production or altered germination stimulant composition provides a sustainable and most effective way for managing the parasitic weeds. Integrated striga management approaches such as a combined use of Striga resistant varieties and Fusarium oxysporum fsp. Strigae (FOS), a biocontrol agent of striga, is an option to control the parasite and to boost sorghum productivity. Understanding host gene action influencing striga resistance, with or without FOS treatment, is key to develop improved sorghum varieties with durable resistance and high yield. Varying levels of resistance have been identified and exploited in the breeding programs of several crops. Considerable efforts have been invested in breeding for striga resistance in cereals and significant progress has been made in the development of improved selection methods.
\end{abstract}

Keywords: Striga; Parasite; Sorghum; Hosts; Resistance; Haustoria; Strigolactones

\section{INTRODUCTION}

Sorghum [Sorghum bicolor $(\mathrm{L}$.$) Moench; 2 \mathrm{n}=20$ ] is the fifth most important cereal cultivated worldwide after maize, rice, wheat and barley and is mainly grown in semi-arid tropical regions for food and fodder (FAO, 2019). Sorghum is naturally self-pollinated monocotyledon crop with the degree of spontaneous cross pollination, in some cases, reaching up to 30\% depending on panicle type (Poehlman and Sleper, 1995). Sorghum is belongs to the $C_{4}$ family with a high photosynthetic activity and drought to prance, therefore it is cultivated in almost all temperate and tropical climatic areas (Miri et al., 2012). The origin and the early domestication of sorghum took place in northeaster Africa approximately 5000 years ago (Mann et al., 1983). Ethiopia is the country of origin for sorghum and has domesticated with wide ranges of collections for various agro-ecologies (Doggett, 1988). The genus sorghum, originated from a diverse array of African environments. Hence, sorghum shows an unlimited range of phenotypic diversity and varied resistance to biotic and abiotic stresses (Kimber et al., 2013). Sorghum has a remarkable wide adaptation and tolerance to high temperatures, high evaporative demand, inadequate 
and erratic rainfall and soils of poor structure, low fertility and low water holding capacity (Teshome et al., 2007).

Sorghum is a drought-tolerant crop of major importance for food security in Africa (Doggett H, 1988). The sorghum grain crop has played a fundamental role in adaptation to environmental change in the Sahel since the early Holocene, when the Sahara desert was a green homeland for Nilo-Saharan groups pursuing livelihoods based on hunting or herding of cattle and wild grain collecting (Bellwood, 2013). Sorghum is the main staple food crop for more than 500 million people in Africa, Asia and Latin America particularly in semi-arid tropical regions where drought is the major limitations to food production (Ejeta, 2007). About two third of sorghum grain produced worldwide is used for human consumption in developing countries (Ejeta, 2007). Its adaptations to drought, heat and low nutrient availability, made sorghum especially important for agriculture in sub-Saharan Africa, where it is a staple food, feed and forage (Mace et al., 2013). Sorghum is an economically important cereal grain which is grown as a food crop by small-scale farmers in sub-Saharan Africa (SSA) (FAOSTAT, 2016). Sorghum serves as source of food, feed, and energy to humankind in marginal areas of sub-Saharan Africa, where soils are poor, rains are erratic and other crops do not do well (Kimber et al., 2013).

The sorghum crop is highly productive, drought tolerant and has fibrous root structure that can infiltrate up to 8 feet inside the soil to obtain essential nutrients and water. Sorghum is a major food staple in Sub-Saharan Africa (SSA), but its production is constrained by the parasitic plant striga that attaches to the roots of many cereals crops and causes severe stunting and loss of yield. Parasitic weeds of the genus striga constitute a major constraint to sorghum production, particularly in the drier parts of the world. Striga is a serious biotic constraint to cereal production in the dry savannas of Sub-Saharan Africa where over 100 million people lose half their crop production to this hemi-parasitic weed (Kanampiu et al., 2018). In West Africa, striga infests over 64\% (17 million ha) of the land planted to cereals, resulting in significant yield losses that range from 10 to $100 \%$ depending on crop and cultivar (Gressel et al., 2004). The parasitic plants, striga asiatica and striga hermonthica, cause serious yield penalties in subsistence and commercial sorghum production. Striga is an obligate root parasite, which seeds will not germinate unless it receives a chemical signal from a potential host plant.

This parasitic weed completes its life cycle beneath the ground more than 80 percent and emerged above the ground only for stem formation and seed setting. During the life cycle below ground, it forms haustorium, attaches and penetrates the host root cortex cells and sucking nutrients, minerals and water from it and cause final damage of host life (Ejeta, 2007). Production of cereal crops including sorghum in sub-Saharan Africa is highly constrained by parasitic weed known as striga (Rich and Ejeta, 2008), that attaches to roots of cereal crops causing severe stunting, necrosis and sometimes cause death of crops resulting to loss of yield (Ejeta and Gressel, 2007). Striga produces numerous tiny seeds which remain viable in the soil for many years and do not germinate unless a sorghum, millet or maize root grows very near to them. Once established, it is therefore very hard to eradicate and in some areas where infestation is heavy, there may be total crop failure in some years (Westwood et al., 2010). The problem caused by striga is steadily increasing as population pressures result in more continuous cereal cultivation. Striga is favored by low fertility and unreliable rainfall and affects the srnall-scale farmers who are least productive and least able to afford any inputs for its control (Musyoki et al., 2015).

The genus striga belongs to family Orobanchaceae and comprises 30 to 35 species and over $80 \%$ of these species are found in Africa while the rest occur in Asia (Westwood et al., 2012). Striga asiatica and S. hermonthica infect cereals including sorghum, maize, upland rice and wheat while S. gesnerioides infects tobacco and cowpea (Ejeta and Gressel, 2007). Among the striga species S. hermonthica is the most widely spread (Parker, 2009) and this is caused by increase of areas cultivated with susceptible host crops, suitable climate, mono-cropping and reduced soil fertility (Gressel, 2009). In addition to commonly known Striga species, S. forbesii and S. aspera are known to have random effects on infected cereal crops within their habitats (Westwood et al., 2012). The root-parasitic weed Striga is a serious threat to food security in sub-Saharan Africa. The parasite is one of the most serious pests limiting yields of the major cereal crops, maize, pearl millet and sorghum (Ejeta, 2007). The parasitic nature of striga on sorghum and its negative impact on growth and grain yield of sorghum had long been established by different researchers. For example, Bebawi and Farha (1981) reported that the parasitic striga weed causes reduction in sorghum grain yield by $65 \%$ when compared with $32 \%$ caused by non-parasitic weeds. 
The problem caused by striga species infestation is expected to grow worse due to its adaptive ability of parasitizing new crops or varieties and adaptation to new environmental conditions. Striga is also infamously known as witchweed and can destroy a crop with up to a 100\% yield loss (Ejeta, 2007). It is estimated that over $60 \%$ of farmland under cultivation in Sub-Saharan Africa (SSA) is infested with one or more species of striga, which impacts over 300 million farmers in over 25 countries with yield losses of over seven billion dollars (Ejeta, 2007). The annual yield loss due to Striga alone was estimated at US $\$ 7$ billion in sub-Saharan Africa, posing a major threat to the livelihood of over 100 million people (Badu-Apraku and Akin wale, 2011). Striga is a severe problem in the cereal growing regions of northern and Eastern Ethiopia (Fasil et al., 2010). Growing sorghum repeatedly on the same field increases the striga population so much that further cultivation is uneconomical. Infested area and level are likely to increase in the near future because of continued increase in cereal monoculture in some parts of Africa that has led to reduced soil fertility coupled with high moisture stress, and the weed has consequently been described as an indicator of low soil fertility (Teka, 2014). The objective of the paper was to understand the effects of striga on sorghum production and its integrated management approaches.

\section{ORigin, Classification, Distribution AND InfESTation Of STRIGa}

Striga weed is believed to have originated between Nubian hills of Sudan and Semien Mountains of Ethiopia (Atera et al., 2011). This region is also the birthplace of domesticated sorghum (Sorghum bicolor L.), which is a major host species for several striga species, including S. hermonthica. Striga are obligate root-parasitic plants of the major agricultural cereal crops, including millets, in tropical and semi-arid regions of Africa, Middle East, Asia and Australia (Parker, 2009). Striga belongs to Orobanchea family, which has high numbers of parasitic species (Bennett and Mathews, 2006). Among the striga genus, 30 species have been described to parasitize grass species (Poaceae) and one species, which parasitize legumes (Mohamed and Musselman, 2008). Currently, striga spps of economic value are S. hermonthica, followed by S. asiatica, S. gesnerioides and less extent, S. forbesi and S. aspera (Parker, 2009). Striga species are classified into two major groups, autogamous and obligate allogamy. Striga asiatica is classified as autogamous species; does not require pollinators while S. hermonthica and S. aspera are both allogamy; requires insects for pollination (Mohamed and Musselman, 2008). Genetic variation in sub population of S. hermonthica is contributed by its cross breeding nature (Berner et al., 1997). Morphologically, S. gesneriodes is different from other species of striga (Estep et al., 2012) in that, haustoria of S. gesnerioides has branched vascular system and lacks hyaline body.

Striga weeds are extensively distributed all over the world however; they are generally innate in tropical and semi-arid areas of Africa (Ejeta and Gressel, 2007). Striga curviflora, S. multiflora and S. parviflora are striga spps native to Australia while S. asiatica was innate in tropical parts of Africa and Asia but now days is found in Carolina in United States of America (Mohamed and Musselman, 2008). Striga gesnerioides is inborn in Asia, Africa, and Arabia but now days is found in United States (Mohamed and Musselman, 2008) while S. hermonthica dominates semi-arid areas of Northern Tropical Africa, the Democratic Republic of Congo, South West Arabia and Southern tropical Africa (Parker and Riches, 1993). In Africa, 25 countries had been reported to be infested with striga by year 2005 (Groote et al., 2008). Striga infests important staple crops including sorghum, maize, wheat, rice, sugarcane and cowpea which are of social and economic important to local farmers in areas affected (Atera et al., 2011). Plants infested by striga weeds display severe symptoms characterized by chlorosis, leaf lesions, leaf desiccations, stunted growth and necrosis (Berner et al., 1997). Striga in SSA has been estimated to affect the lifestyle of 300 million people per year and economic damage of about 7B USD.

Striga species are obligate parasitic weeds which attach themselves to the roots of cereals and other plants, not only robbing them of nutrition but also causing various debilitating effects. The two most important species (S. hermonthica and S. asiatica) parasitize cereal crops, particularly sorghum and millets, but also maize, upland rice and sugarcane. Parasitism of sorghum by S. hermonthica and reduction of its growth and grain yield due to this parasitic weed had also been reported by Showemimo (2006) as well as by Runo and Kuria (2018). There are many reports on the allelopathic nature of sorghum on weeds too (Alsaadawi and Dayan, 2009) as well as other crops or plants on sorghum (Hassan et al., 2013). Reports show that chemicals released from a given species upon decomposition may be allelopathic to itself too and inhibit germination and seedling growth of its own. Infestations by $\mathrm{S}$. hermonthica causes severe sorghum yield reduction in which farmers lose sometimes up to 100 
percent grain production (Zerihun, 2015). The percentage yield loss of course depends on factors such as the density of the parasite, sorghum variety, soil nutrient status and rainfall patterns (Atera et al., 2012).

\subsection{Establishment of Striga Parasitism and Completion of the Life Cycle}

When striga xylem connects to the host xylem vessels, parasitism establishment occurs and the parasite shoot emerge which results in production of adventitious roots system. Secondary haustorium are formed from these adventitious roots system and are believed to be evolutionary older than primary haustoria and can infect the same or other host plants (Westwood et al., 2010). In ordinary conditions, the host plants are infested by huge numbers of striga weeds and this parasitism makes striga weed to become metabolic sink for photo assimilates and nutrients (Knutson, 2012). Cultivated sorghum plants affected by $\mathrm{S}$. hermonthica display reduction in photosynthetic parameters including electron transport rate through photochemical quenching and photo system (Rodenburg and Bastiaans, 2011). Also elevation of plant hormones such as abscisic acid and cytokinins levels in sorghum plants due to parasitism by S. hermonthica have shown to have negative effects on photosynthesis (Frost et al., 1997). Once striga weed emerges above the ground, it starts to photosynthesize, but its leaves are characterized by less number of chloroplasts per cell and a degenerated palisade cell layer (Ranjan et al., 2014). After emergence above the soil, S. hermonthica and S. asiatica flowers after four weeks while S. gesnerioides flowers after two weeks (Berner et al., 1996). The flower color varies between and within species, S. hermonthica and S. gesnerioides varies from blue and pink to white while S. asiatica varies from yellow to red (Ejeta, 2007). Striga seed matures within four weeks after pollination in seedpods and after bursting of seedpods, the seeds spread above the ground resulting in increases of striga seeds density in the soil (Berner et al., 1997).

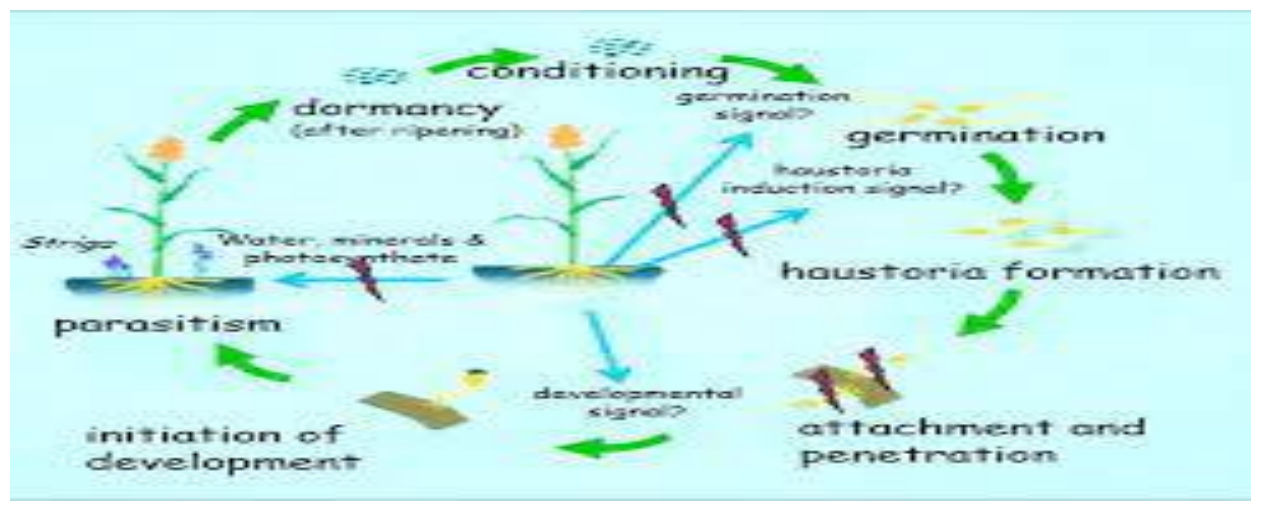

Figure 1: Illustrated Striga life cycle (Ejeta et al., 1993)

\subsection{Economic Implication of Striga in Sorghum Production}

Striga has become the major biological constraints for farmers growing maize, sorghum, millet and rice in SSA (Parker, 2009), causing devastating losses in yield resulting in shortage in food supply in developing countries. Farmers in areas infested with striga weeds report losses of between 20 and $80 \%$ (Atera et al., 2011) and in susceptible cultivars, grain yield losses can end up to 100\% under drought conditions and higher infestation. In Africa striga causes economic loss comparable to USD 1 billion yearly (Labrada and Officer, 2008) and this depends on striga seed density, soil fertility, distribution of rainfall and variety of cereal species grown (Teka, 2014). In sorghum, striga hermonthica infestation affect post flowering stages, resulting to $45 \%$ in grain yield loss (Showemimo, 2010).

Potential yields of sorghum in SSA remains low because of factors such as poor agronomic practices, lack of commercialization of the crop which has resulted in low usage of productivity and striga weeds problem which affects sorghum growing areas. Striga infection causes disruption of host plant development resulting in retarded growth, necrosis and general drought-like prone like before it appears above the ground. The severiarity of striga infection depends on several factors including host genotype, infection time and level, the nitrogen content in soil and striga species and ecotypes (Gurney et al., 2006). Striga species (witch weeds) are parasitic weeds growing on the roots of cereal and legume crops in dry, semi-arid, and harsh environments of tropical and subtropical Africa, Arabian Peninsula, India, and a small part of USA. In some parts of Africa the profusion of witch weeds have serious impact on 
the socio-economic life of farmers. Heavily infested farms are abandoned and occasional migrations of farming communities because of striga have been reported. It is endemic in Africa's cereal and legume food crop production.

The weed is parasitic to cereals and legumes, but there is significant variation in the reaction of different crop species. Because striga has evolved, parallel with sorghum, over the centuries, the indigenous crop has developed the whole spectrum of tolerance (on average about 60\%), susceptibility (in about $30 \%$ ), and resistance (in about $10 \%$ ). On the other hand, in maize, susceptibility has been the common reaction as resistant varieties are still being identified and confirmed. The reaction of millet is complex, with ecological zone implications. Resistance to striga has not yet been found in millet, even though millet coexists with sorghum in some environments. Reaction of rice to striga is not well known, but indications are that susceptibility to striga parasitism is normal in rice. The cowpea, Vigna unguiculata, is the legume most affected by striga in dry areas of Africa, where it is a common food plant. Being an obligate hemi parasite, striga causes tremendous damage to the host plants before striga emerges from the soil. Persistent drought worsens the situation. As a result the striga problem is one of the most serious production problems on cereals and cowpeas south of the Sahara. In these striga-infested regions, the environment is so harsh and marginal for crop productivity that only a few drought-resistant staple crops are grown sorghum, millets, cowpeas, and some maize and they are extremely parasitized.

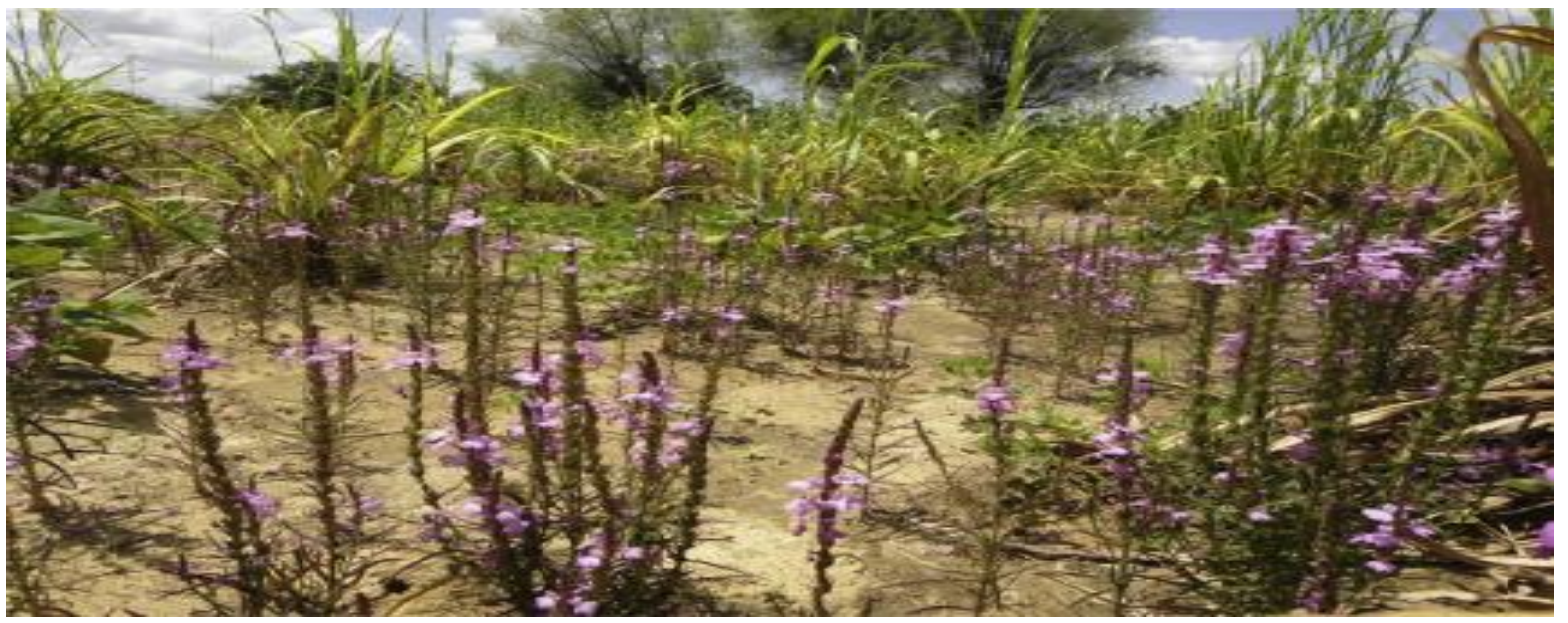

Figure1. A Striga affects millions of smallholder farmers in sub-Saharan Africa (Mignouna et al., 2013)

\subsection{Low Germination Stimulant Production}

Sorghum genotypes with low germination stimulant (LGS) produce low amounts of the exudates essential for stimulation of germination of pre-conditioned striga seeds (Hauck et al., 1992). These genotypes producing insufficient germination stimulants are known to resist to striga infestation. Sorghum genotypes susceptible to striga are known to produce high amounts of germination stimulants although not all sorghum genotypes which are resistant to striga do produce low germination stimulants (Ejeta and Gressel, 2007). There are several classes of chemical signals for striga seed germination, but the most common and important one is strigolactones (Hauck et al., 1992). In sorghum low germination stimulant (LGS) trait which is known to have high addictive gene action is transferred to off-springs as a single, nuclear, recessive gene. Sorghum cultivars with this mechanism are Framida, SRN 39, 555, SAR lines, IS 15401 and IS 9830.

\subsection{Low Production of the Haustoria Initiation}

Germinated striga seeds near the roots of sorghum genotypes with low production of the haustorial initiation factor (HIF) do not form haustoria and therefore die from their inability to attach to their potential host (Gurney et al., 2006). Signals for striga seeds germination have been identified unlike signals for haustoria induction which have not yet been identified, but a large number of phenolic compounds have shown to function as haustoria initiators in striga. A simple Quinone, 2, 6 dimethoxy1, 4-benzo quinine (DMBQ), though not present in host root exudates has been shown to act as a strong haustorial initiating factor (Smith, D.L, 1998). Extended agar gel assay (EAGA) is used to study low production of haustorial initiation factors by distinguishing host genotypes qualitatively on their ability to induce haustorial formation. 


\subsection{Host Plant Cellular Aspects against Striga Parasitism}

There are two essential stages for striga survival during host parasitism; successful breaching of host root system and subsequent formation of vascular connection (Timko et al., 2012). During these developmental stages, the host can mount resistance response that can block parasite development (Timko et al., 2012). Three broad categories of resistance response against parasitism have been revealed using histological analysis (Hood et al., 1998). Susceptible striga parasitism is observed when the host plant fails to respond to the penetrating haustorial peg or inability to activate cascade responsible for turning on defense response (Gurney et al., 2006). On the other hand, resistance response can either delay or be immediate during various developmental stages of parasite (Timko et al., 2012). Several mechanisms are known involved for inducing immediate resistance response against striga parasitism (Spallek et al., 2013). After parasitic attachment (within 24-72 hours), phenolic compounds accumulate at the interface of parasite host and this has been reported in S. hermonthica and sorghum (Jamison and McClung, 2003). The accumulation of these phenolic compounds leads to build up of physical barriers including; thickening of cell walls as result of lignin, cellulose or suberin deposition at attachment site of parasite to host root (Lane et al., 1997). Hypersensitive response (HR) characterized by browning and localized host cell death has been observed in cowpea cultivars resistance to S. gesnerioides (Lane et al., 1997) also in accessions of wild sorghum and some sorghum cultivars against S. asiatica parasitism (Mohamed et al., 2003). Host root endodermis has been reported to confer resistance response in many cereals including sorghum against $\mathrm{S}$. asiatica parasitism and rice against S. hermonthica parasitism (Gurney et al., 2006).

After successful parasitism, resistant response can also occur, taking a number of forms. In one form, host vessels can be sealed by gel or gum-like substance in order to block the flow of nutrients and water to parasite from the host plant. In another form, the parasitized plant can transfer toxic compounds to the parasite through its haustorium (Scholes and Press, 2008). The observed resistance mechanisms against parasitic plants can broadly be categorized into post-attachment resistance and pre-attachment (Rodenburg and Bastiaans, 2011). The pre-attachment resistance mechanisms comprises all mechanisms that enable potential host to evade parasitism; inhibition of germination of striga seeds, reduced production germination stimulant, haustorium formation inhibition, haustorium development inhibition and thickening in cell walls of host roots preventing the haustorium from penetrating host roots (Rodenburg and Bastiaans, 2011). Parasite will try to breach the host root vascular system once the haustorium forms. During these parasite developmental stages, host could induce different postattachment resistance mechanisms including; cell wall lignification, programmed cell death (PCD) as result of necrosis at the location of parasite attachment to host root and abiosis release cytotoxic compounds within infected host cells (Rodenburg and Bastiaans, 2011).

\section{Striga Management Approaches}

In Africa, food security is highly affected by striga weeds infestation and therefore control measures must be implemented to mitigate the negative effects (Atera et al., 2012). Management of striga weeds is difficult as each striga flower spike produces huge number of seeds (Gethi et al., 2005) and these seeds can remain dormant for over 14 years in the soil, germinating only in response to chemical cause expressed by host roots (Bouwmeester et al., 2003). Control methods for striga include; crop rotation, intercropping, transplanting, soil and water management, application of fertilizers, use of herbicide's (Oxyfluorfeen, 2- 4 D and Imazapyr), hand weeding and push and pull. All these methods are based on reduction of striga seeds density already in soil, but they are not effective because they are expensive, time consuming, labor intensive and cereals are overcome by emerging races and out crossing of striga species (Ejeta, 2007). However technique such as next-generation sequencing have recently been used to understand the molecular basis of striga parasitism in host plants (Yoder and Scholes, 2010). These in silico techniques will enable identification of striga resistance genes in wild sorghum accession and provide valuable data for selection of genes responsible for striga resistance in wild sorghum accessions. This techniques are used to study association of genes in parasite and host interactions during resistant and susceptible interactions. During incompatible interactions of Tagetes erecta and S. asiatica, 23 genes were identified whose expression were up-regulated in the roots after infection (Gowda et al., 1999). Cultivated cereals do not express complete resistance to striga infestation, however, striga species distribution in a natural ecosystem is usually scarce but abundant in agro-ecosystem. The wild grasses contain a resistance mechanism that enables them to resist Striga infection resulting in low 
amount of these striga species in wild grassland as compared to cultivated cereals (Hearne, 2009). In Africa, a study on Savanna grasses showed resistance to $S$. hermonthica by displaying impaired normal parasite development (Kuiper et al., 1998). There is a possibility for wild relatives of the cultivated sorghum to provide genetic basis for resistance or tolerance to striga infection and may be of enormous value for the development of striga resistant crops.

Parasitic plants are difficult to control because by the time they emerge above the ground, they have done greater damage to crops (Ransom et al., 2012). In addition, the parasite produces huge numbers of seeds of about 20000-600000 (Yoder and Musselman, 2006). To manage striga, small-scale farmers have engaged in different control approaches with the aim of reducing the quantity of striga seed in the soil. The recent control approaches for striga comprises of cultural and mechanical practices, planting resistant crops, biological control practices, use of nitrogen fertilizers and chemicals/herbicides (Jamil et al., 2011). Cultural practices recommended for striga control include; crop rotation, intercropping, transplanting, soil and water management, application of fertilizers and hand weeding (Ransom et al., 2012). These methods are based on reduction of striga seeds density already in soil (Reda and Verkleij, 2007). These practices are of less success for small-scale farmers due to financial and socio-economic limits. However, planting resistant crops is much preferred because they are friendly to environment, easy to handle, affordable and cheaper to local farmers in SSA (Yoder and Scholes, 2010).

It is now well recognized that no single method of control can effectively solve the striga problem. Striga species are weeds and they are parasites. As weeds, they appear late in the season, and escape the normal early weeding operations. As parasites, they have the advantage of remaining out of sight (and frequently out of mind) while feeding on the host. The three major principles of striga control are: (1) reduction of seed numbers in the soil; (2) prevention of new seed production; and (3) prevention of movement of seeds from infested to non-infested areas. Any control strategy should include an integration of at least one method from each of these three major principles.

Table1. Striga control methods described under three principles

\begin{tabular}{|l|l|l|}
\hline $\begin{array}{l}\text { I. Reducing number of Striga seeds } \\
\text { in soil }\end{array}$ & $\begin{array}{l}\text { II. Preventing production of new } \\
\text { seeds }\end{array}$ & $\begin{array}{l}\text { III. Preventing spread from } \\
\text { infested to non-infested soils }\end{array}$ \\
\hline 1. Cultural & Resistant varieties & 1. Cultural \\
\hline Trap crops & Hand weeding & Antisoil erosion \\
\hline Catch crops & Irrigation/flooding & 2. Phytosanitary practices \\
\hline Deep plowing & Date of sowing & Clean seed \\
\hline Soil solarization & $\begin{array}{l}\text { 3.Feeding only striga-free fodder } \\
\text { to livestock }\end{array}$ \\
\hline 2. Chemical & Fertilizers/manures & \\
\hline Methyl-bromide fumigation & Density of sowing/shading & \\
\hline $\begin{array}{l}\text { Germination stimulants (Ethylene } \\
\text { gas and strigol analogs) }\end{array}$ & 2. Chemical & \\
\hline & Herbicides & \\
\hline & 3. Biological & \\
\hline
\end{tabular}

There are three general options available for striga control: a) genetic (using resistant varieties); b) agronomic (using cultural manipulation and chemicals); and c) biological (using insect pests and pathogens).

\subsection{Cultural practices}

Several cultural methods were reported to be efficient in controlling striga species (Ramaiah, 1987). Some include use of costly inputs such as fertilizers, some are labor-intensive, like hand weeding, and some involve minor adjustments in the cropping systems-such as crop rotations. Among these, hand weeding is most often recommended to third World farmers and is also the one often rejected, mainly because of its low cost-benefit ratio. Extension workers emphasize the importance of hand weeding as soon as the striga plants emerge, but most of the damage to the host has occurred while the striga is still in the soil. Hand removal of striga helps reduce population buildup, and thus is helpful in the long run, but farmers seldom think beyond 2 or 3 years ahead. In most nations of western and southern Africa, land ownership is non-existent. Farmers seldom undertake long-term strategies to control striga or improve the soil by anti-erosion measures, crop rotation, or trap cropping. The dramatic reduction of 
striga populations in the following 2 years provided evidence that a majority of the seeds still on the striga plants were destroyed when the plants were pulled and burned.

This method along with resistant varieties, fertilizers, and other cultural practices known to reduce striga populations could be used very effectively as a supplementary control method. Hand weeding may then become more practical, and perhaps a common practice. In Jordan, Syria, and Israel solar energy was used successfully for the control of Orobanchea, a closely related parasitic species. The process is called soil solarization: It killed Orobanchea seeds effectively when the soil was covered with polyethylene for about 40 days following summer irrigation. This was found to be very effective, like methyl bromide fumigation, but less toxic. It has been effective on other soil borne pathogens, including the pigeon pea Fusarium wilt disease in India. In developing countries, weeds continue to be one of the most important contributing factors to yield loss in agricultural production. Significant weed seed bank increments through prolific seed production, competition for water and nutrients, cost associated with seed cleaning are the main striga weed to contribute for crop yield losses.

\subsection{Chemical Methods}

Excellent pre- and post-emergence striga herbicides are now available (Eplee and Norris 1987a). In addition, fumigants like methyl bromide and germination stimulants like ethylene gas effectively reduce striga seed reserves in infested soils. Fumigants, however, are most expensive for use by the small-scale farmer. Though herbicides are available to control striga as it emerges or later to prevent seed production, using them does not prevent the damage inflicted by pre-emergent parasitic attachment. This limitation is now overcome by the discovery of systemic herbicides (Eplee and Norris 1987b). In USA, Dicamba ${ }^{\circledR}$ is used on sorghum and maize to kill striga before crop yields are reduced. Dicamba ${ }^{\circledR}$ sprayed at $0.5 \mathrm{kgha}^{-1}$ on sorghum or maize no taller than $1 \mathrm{~m}$ gave excellent control of striga without reduction in yield.

\subsection{Host resistance Methods}

A crop genotype which, when grown under conditions of striga infestation, supports significantly fewer striga plants and has a higher yield than a susceptible cultivar is called resistant (Doggett, 1988). In contrast, tolerant cultivars show smaller yield reductions than susceptible cultivars under the same level of infestation. Cultivation of tolerant cultivars can lead to an increased striga seed bank over time (Doggett, 1988). Development of sorghum germ-plasm that is resistant to striga weed infestation seems to be elusive (Hearne, 2009). Currently, there is no effective method for striga control, yet sorghum production in SSA is highly affected by striga weeds leading to $45 \%$ in grain yield loss (Showemimo, 2010). Cultivated sorghums have limited sources of striga resistance in additions the cultivated varieties which showed tolerance and resistance to striga now are overcome by emerging races of striga weeds (Parker, 2009).

Therefore, there is a need to find additional sources of striga resistance for introduction in farmers' preferred cultivated races for long-term resistance. However, wild relatives of these cultivated sorghums shows striga resistance in native grasslands and therefore wild sorghum provides a potential source of striga resistance for developing host derived resistance (Gurney et al., 2002). Screening a wide range of wild relatives of sorghum and identifying key resistant genes from differentially expressed ones, between striga susceptible cultivated varieties and striga resistant wild sorghum via intensive transcriptomics approaches will provide valuable data to select genes responsible for striga resistance. This will be of fundamental importance in developing durable and broad based resistance against striga and has far-reaching implications in developing resistance in other important cereal crops in SSA.

\subsection{Biological Control Methods}

The objectives of weed biological control is not the eradication of weeds but the reduction and establishment of a weed population to a level below the economic threshold. Means biological control of weeds comprise herbivorous insects, microorganisms (especially fungi) and smother plants (Sauerborn and Kroschel, 1996). The method involves importation, colonization and establishment of exotic natural enemies, which includes predators and parasitoids. Biological control is considered as a potential cost-effective, safe and environmentally beneficial means of reducing weed populations in crops, forests and rangelands (Charudattan, 2001). 
Biological control is particularly attractive in suppressing root parasitic weeds in annual crops because of the intimate physiological relationship with their host plants makes it difficult to apply conventional weed control measures. Currently, biological control using microbes is becoming a critical component of integrated management of striga, given that the bio-control agents are usually host specific, highly aggressive, easy to mass produce and diverse in terms of the number of isolates. Biological control methods are also relatively economical, may be self-perpetuating and are usually free from negative residual effects. Management of striga through bio-control agents is also much safer and less polluting to the environment than the use of chemical pesticides (Abbasher et al., 1998).

\section{CONCLUSION}

Sorghum is an important food, feed, and industrial crop worldwide. Sorghum is a key staple crop for millions of people in Sub-Saharan Africa and used for different purpose. Sorghum is a major food staple in Sub-Saharan Africa, but its production is constrained by the parasitic plant striga that attaches to the roots of many cereals crops and causes severe stunting and loss of yield. Potential yield of sorghum in the semi-arid agro-ecologies of East Africa is curtailed by several biotic, abiotic and socio-economic constraints. Striga is one of the major biotic constraints that causes up to $90 \%$ yield losses in sorghum in the region. In these regions Striga hermonthica and S. asiatica, are widely distributed, and severely affecting sorghum production and productivity.

Witch weeds (Striga spp.), endemic parasitic weeds of sub-Saharan Africa are steadily increasing their geographic domain and level of infestation, and thereby greatly reducing crop yield. The striga species are among the most specialized of all root-parasitic plant parasites. Parasitic weeds of the genus striga constitute a major constraint to sorghum production, particularly in the drier parts of the world. The parasitic weeds striga are major biotic constraints to sorghum production, especially in the infertile semi-arid areas of Africa. Striga spps are an obligate parasitic plant that attaches to host roots to deplete them of nutrients.

Striga is a serious biotic constraint to cereal production in the dry savannas of Sub-Saharan Africa where over 100 million people lose half their crop production due to this hemi-parasitic weed. Striga reduces yields by competing for water, nutrients, space, light and photosynthesis with the host plants. In Africa, crop yield losses associated with striga related activities is about $40 \%$ and represents an annual loss of cereals worth US\$7 to 13 billion. This problem is further aggravated by the inherent low soil fertility, recurrent drought and overall natural resource degradation because of decades of continuous cereal monoculture and deforestation. Grain yield losses are determined by the levels of resistance and tolerance of the host genotype, by severity of infestation and by the levels of soil fertility.

Striga spps a parasitic weed of grasses, causes major yield reductions in the principal cereal crops of semi-arid Africa. The parasitic weed striga is considered one of the major biotic constraints to food production in Africa, with crop yield losses reaching up to $100 \%$. The search for effective control strategies is urgent and subject of intense study, although no strategy to date is singularly effective. Current control strategies mainly focus on breeding for host resistance. Additionally, cultural methods such as hand weeding and a variety of soil management practices have also been used. Striga spps are difficult to manage effectively because most of its damage to the host plant occurs underground before the parasitic plant emerges and causes serious threat to cultivation of sorghum in areas of insufficient and ill distributed rainfall, and poor soil fertility. Several striga management strategies are available that can be integrated to synergistically combat the weed.

Yields of sorghum in SSA is low due to biotic and abiotic factors including Striga parasitism. Several cultural and chemical control measures are available to control striga. However, these strategies are often poorly adopted by smallholder farmers either due to their unavailability or cost. Integrated striga management involving the use of sorghum genotypes with striga resistance and Fusarium oxysporum fsp. Strigae (FOS) compatibility is an important approach of managing striga and improving sorghum yields in the semi-arid areas. Striga spps (witchweed), are notorious root hemi parasites on cereal and legume crops grown in the semi-arid tropical and subtropical regions of Africa, the southern Arabian Peninsula, India, and parts of the eastern USA. Therefore, the integration of all management approaches are very important for controlling striga devastation below the economic threshold level. 


\section{REFERENCES}

[1] Abbasher, A.A., Hess, D.E. and Sauerborn, J., 1998. Fungal pathogens for biological control of Striga hermonthica on sorghum and pearl millet in West Africa. African Crop Science Journal, 6(2), pp.179-188.

[2] Alsaadawi, I.S. and Dayan, F.E., 2009. Potentials and prospects of sorghum allelopathic in agro ecosystems. Allelopathic Journal, 24(2).

[3] Atera, E.A., Itoh, K. and Onyango, J.C., 2011. Evaluation of ecologies and severity of Striga weed on rice in sub-Saharan Africa.

[4] Atera, E.A., Itoh, K., Azuma, T. and Ishii, T., 2012. Response of NERICA rice to Striga hermonthica infections in western Kenya. International journal of agriculture and biology, 14(2).

[5] Badu-Apraku, B. and Akinwale, R.O., 2011. Cultivar evaluation and trait analysis of tropical early maturing maize under Striga-infested and Striga-free environments. Field Crops Research, 121(1), pp.186-194.

[6] Bebawi, F.F. and Farah, A.F., 1981. Effects of parasitic and non-parasitic weeds on sorghum. Experimental Agriculture, 17(4), pp.415-418.

[7] Bellwood, P., 2013. Neolithic migrations: food production and population expansion. The Global Prehistory of Human Migration, pp.79-86.

[8] Bennett, J.R. and Mathews, S., 2006. Phylogeny of the parasitic plant family Orobanchaceae inferred from photochromic A. American journal of botany, 93(7), pp.1039-1051.

[9] Berner, D., Carsky, R., Dashiell, K., Kling, J. and Manyong, V., 1996. A land management based approach to integrated Striga hermonthica control in sub-Saharan Africa. Outlook on Agriculture, 25(3), pp.157-164.

[10] Berner, D., Winslow, M., Awad, A., Cardwell, K., Raj, D. and Kim, S., 1997. Striga research methods: A manual.

[11] Bouwmeester, H.J., Matusova, R., Zhongkui, S. and Beale, M.H., 2003. Secondary metabolite signaling in host-parasitic plant interactions. Current opinion in plant biology, 6(4), pp.358-364.

[12] Charudattan, R., 2001. Biological control of weeds by means of plant pathogens: significance for integrated weed management in modern agro-ecology. Biocontrol, 46(2), pp.229-260.

[13] Doggett, H., 1988. Sorghum Long Mans. 2nd (Ed.). Green and Co ltd. London, P, 40-41.

[14] Ejeta, G. 2007. Breeding for Striga resistance in sorghum: exploitation of an intricate host parasite Biology Crop Science 47:216-227.

[15] Ejeta, G. and Gressel, J., 2007. Integrating new technologies for Striga control: towards ending the witchhunt. World Scientific.

[16] Eplee, R.E. and Norris, R.S., 1987. Chemical control of Striga. Parasitic weeds in agriculture. Volume I. Striga., pp.173-182.

[17] Eplee, R.E. and Norris, R.S., 1987. Field research techniques. Parasitic weeds in agriculture. Volume I. Striga., pp.271-280.

[18] Estep, M.C., Gowda, B.S., Huang, K., Timko, M.P. and Bennetzen, J.L., 2012. Genomic characterization for parasitic weeds of the genus Striga by sample sequence analysis. The Plant Genome, 5(1).

[19] FAOSTAT 2016, Database of agricultural production FAO Statistical Databases (FAOSTAT) http://faostat.fao.org/default.aspx.

[20] Food and Agriculture organization of the United Nation statistical division (FAOSTAT), 2019. http://faostat3. fao.org/home/E.

[21] Frost, D.L., Gurney, A.L., Press, M.C. and Scholes, J.D., 1997. Striga hermonthica reduces photosynthesis in sorghum: the importance of stomatal limitations and a potential role for ABA. Plant, Cell \& Environment, 20(4), pp.483-492.

[22] Gethi, J.G., Smith, M.E., Mitchell, S.E. and Kresovich, S., 2005. Genetic diversity of Striga hermonthica and Striga asiatica populations in Kenya. Weed Research, 45(1), pp.64-73.

[23] Gowda, B.S., Riopel, J.L. and Timko, M.P., 1999. NRSA-1: a resistance gene homolog expressed in roots of non-host plants following parasitism by Striga asiatica (witchweed). The Plant Journal, 20(2), pp.217-230.

[24] Gressel, J., 2009. Crops with target-site herbicide resistance for Orobanche and Striga control. Pest Management Science: formerly Pesticide Science, 65(5), pp.560-565. 
[25] Gressel, J., Hanafi, A., Head, G., Marasas, W., Obilana, A.B., Ochanda, J., Souissi, T. and Tzotzos, G., 2004. Major heretofore intractable biotic constraints to African food security that may be amenable to novel biotechnological solutions. Crop Protection, 23(8), pp.661-689.

[26] Groote De., Wangare, L., Kanampiu, F., Odendo, M., Diallo, A., Karaya, H. and Friesen, D., 2008. The potential of an herbicide resistant maize technology for Striga control in Africa. Agricultural Systems, 97(1-2), pp.83-94.

[27] Gurney, A.L., Press, M.C. and Scholes, J.D., 2002. Can wild relatives of sorghum provide new sources of resistance or tolerance against Striga species? Weed research, 42(4), pp.317-324.

[28] Gurney, A.L., Slate, J., Press, M.C. and Scholes, J.D., 2006. A novel form of resistance in rice to the angiosperm parasite Striga hermonthica. New Phytologist, 169(1), pp.199-208.

[29] Hassan, M.M., Daffalla, H.M., Modwi, H.I., Osman, M.G., Ahmed, I.I., Gani, M.E.A. and Abdel El Gabar, E.B., 2013. Effects of fungal strains on seeds germination of millet and Striga hermonthica. Universal Journal of Agricultural Research, 2(2), pp.83-88.

[30] Hauck, C., Müller, S. and Schildknecht, H., 1992. A germination stimulant for parasitic flowering plants from Sorghum bicolor, a genuine host plant. Journal of Plant Physiology, 139(4), pp.474-478.

[31] Hearne, S.J., 2009. Control-the Striga conundrum. Pest Management Science: Formerly Pesticide Science, 65(5), pp.603-614.

[32] Hood, M.E., Condon, J.M., Timko, M.P. and Riopel, J.L., 1998. Primary haustorial development of Striga asiatica on host and non-host species. Phytopathology, 88(1), pp.70-75.

[33] Jamil, M., Rodenburg, J., Charnikhova, T. and Bouwmeester, H.J., 2011. Pre-attachment Striga hermonthica resistance of New Rice for Africa (NERICA) cultivars based on low strigolactones production. New Phytologist, 192(4), pp.964-975.

[34] Jamison and McClung, D.S., 2003. Haustorium development in the parasitic plant, Triphysaria (Orobanchaceae): A genetic and molecular analysis. University of California, Davis.

[35] Kanampiu, F., Makumbi, D., Mageto, E., Omanya, G., Waruingi, S., Musyoka, P. and Ransom, J., 2018. Assessment of management options on Striga infestation and maize grain yield in Kenya. Weed Science, 66(4), pp.516-524.

[36] Kimber, C.T., Dahlberg, J.A. and Kresovich, S., 2013. The gene pool of Sorghum bicolor and its improvement. In Genomics of the Saccharinae (pp. 23-41). Springer, New York, NY.

[37] Knutson, D.M., 2012. How parasitic seed plants induce disease in other plants. Plant disease, 102(4), pp.293312.

[38] Kuiper, E., Groot, A., Noordover, E.C., Pieterse, A.H. and Verkleij, J.A., 1998. Tropical grasses vary in their resistance to Striga aspera, Striga hermonthica, and their hybrids. Canadian Journal of Botany, 76(12), pp.21312144.

[39] Labrada, R. and Officer, W., 2008. Farmer training on parasitic weed management. Progress on farmer training in Parasitic Weed Management, 4(11), pp.1-5.

[40] Lane, J.A., Moore, T.H.M., Child, D.V. and Bailey, J.A., 1997. Variation in virulence of Striga gesnerioides on cowpea: new sources of crop resistance. Advances in cowpea research, 84(2), pp.225-230.

[41] Mann, J.A., 1983. The relationship of germination parameters to field adaptation and heat stress tolerance in Sorghum bicolor (L.) Moench (Doctoral dissertation, Texas A\&M University).

[42] Mignouna, B.D., Abdoulaye, T., Kamara, A. and Oluoch, M., 2013. Baseline study of smallholder farmers in Striga-infested maize and cowpea-growing areas of northern Nigeria. International Institute for Tropical Agriculture, Ibadan, Nigeria, 60.

[43] Miri, K., Rana, D.S., Rana, K.S. and Kumar, A., 2012. Productivity, nitrogen-use efficiency and economics of sweet sorghum (Sorghum bicolour) genotypes as influenced by different levels of nitrogen. Indian journal of Agronomy, 57(1), pp.49-54.

[44] Mohamed, A., Ellicott, A., Housley, T.L. and Ejeta, G., 2003. Hypersensitive response to Striga infection in sorghum. Crop science, 43(4), pp.1320-1324.

[45] Mohamed, K.I. and Musselman, L.J., 2008. Taxonomy of agronomically important Striga and Orobanche species. Progress on farmer training in parasitic weed management, 41(3), pp.7-14. 
[46] Musyoki, M.K., Cadisch, G., Enowashu, E., Zimmermann, J., Muema, E., Beed, F. and Rasche, F., 2015. Promoting effect of Fusarium oxysporum [f. sp. strigae] on abundance of nitrifying prokaryotes in a maize rhizosphere across soil types. Biological Control, 83, pp.37-45.

[47] Parker, C. and Riches, C.R., 1993. Parasitic weeds of the world: biology and control. CAB international.

[48] Parker, C., 2009. Observations on the current status of Orobanche and Striga problems worldwide. Pest Management Science: formerly Pesticide Science, 65(5), pp.453-459.

[49] Poehlman JM and Sleper DA (1995). Breeding Field Crops. 4th Ed, Iowa State University Press, Ames, Iowa.

[50] Ramaiah, K.V., 1987. Control of Striga and Orobanche species-a review. In Proceedings of the 4th international symposium on parasitic flowering plants. (pp. 637-664).

[51] Ranjan, A., Ichihashi, Y., Farhi, M., Zumstein, K., Townsley, B., David-Schwartz, R. and Sinha, N.R., 2014. De novo assembly and characterization of the transcriptome of the parasitic weed dodder identifies genes associated with plant parasitism. Plant Physiology, 166(3), pp.1186-1199.

[52] Ransom, J., Kanampiu, F., Gressel, J., De Groote, H., Burnet, M. and Odhiambo, G., 2012. Herbicide applied to imidazolinone resistant-maize seed as a Striga control option for small-scale African farmers. Weed Science, 60(2), pp.283-289.

[53] Reda, F. and Verkleij, J.A.C., 2007. Cultural and cropping systems approach for Striga Management-a low cost alternative option in subsistence farming. In Integrating New Technologies for Striga Control: Towards Ending the Witch-Hunt (pp. 229-239).

[54] Rich, P.J. and Ejeta, G., 2008. Towards effective resistance to Striga in African maize. Plant Signaling \& Behavior, 3(9), pp.618-621.

[55] Rodenburg, J. and Bastiaans, L., 2011. Host-plant defense against Striga spp.: reconsidering the role of tolerance. Weed Research, 51(5), pp.438-441.

[56] Runo, S. and Kuria, E.K., 2018. Habits of a highly successful cereal killer, Striga. PLoS pathogens, 14(1), p.e1006731.

[57] Sauerborn, J., Abbasher, A.A., Kroschel, J., Cornes, D.W., Zoschke, A. and Hine, K.T., 1996, January. Striga hermonthica control with Fusarium nygamai in maize. In Proceedings of the 9th International Symposium on Biological Control of Weeds (pp. 461-466).

[58] Scholes, J.D. and Press, M.C., 2008. Striga infestation of cereal crops-an unsolved problem in resource limited agriculture. Current opinion in plant biology, 11(2), pp.180-186.

[59] Showemimo, F.A., 2010. Effect of Striga hermonthica on yield and yield components of sorghum in Northern Guinea savanna of Nigeria. Journal of Plant Sciences, 5(1), pp.86-90.

[60] Showemimo, F.A., Buah, J.N., Addo-Quaye, A.A. and Asare-Bediako, E., 2006. Nature of inheritance and genetic components of some agronomic traits in sorghum.

[61] Smith, D.L., 1998. The evolutionary ecology of parasitic plants. Princeton University.

[62] Spallek, T., Mutuku, M. and Shirasu, K., 2013. The genus S triga: a witch profile. Molecular plant pathology, 14(9), pp.861-869.

[63] Teka, H.B., 2014. Advance research on Striga control: A review. African journal of plant science, 8(11), pp.492-506.

[64] Teshome A, Patterson D, Asfew Z, Torrance J.K and Arnason JT (2007). Changes of Sorghum bicolor landrace diversity and farmers' selection criteria over space and time, Ethiopia. Genetic Resources and Crop Evolution, 54(6).

[65] Timko, M.P., Huang, K. and Lis, K.E., 2012. Host resistance and parasite virulence in Striga-host plant interactions: A shifting balance of power. Weed Science, 60(2), pp.307-315.

[66] Westwood, J.H., Depamphilis, C.W., Das, M., Fernández-Aparicio, M., Honaas, L.A., Timko, M.P., Wafula, E.K., Wicket, N.J. and Yoder, J.I., 2012. The parasitic plant genome project: new tools for understanding the biology of Orobanche and Striga. Weed Science, 60(2), pp.295-306.

[67] Westwood, J.H., Yoder, J.I., Timko, M.P. and Depamphilis, C.W., 2010. The evolution of parasitism in plants. Trends in plant science, 15(4), pp.227-235.

[68] Yoder, J.I. and Musselman, L.J., 2006. Striga: A subterranean parasitic angiosperm (witchweed). Encyclopedia of plant and crop science. New York, Taylor \& Francis. 
Effect of Striga Species on Sorghum (Sorghum Bicolor L Moench) Production and its Integrated Management Approaches

[69] Yoder, J.I. and Scholes, J.D., 2010. Host plant resistance to parasitic weeds; recent progress and bottlenecks. Current opinion in plant biology, 13(4), pp.478-484.

[70] Zerihun, S., 2015. Effect of nitrogen fertilizer on Striga hermonthica infestation, yield and yield related traits on sorghum [Sorghum bicolor (L.) Moench] varieties at Kile, Eastern Ethiopia (Doctoral dissertation, M. Sc. Thesis, Haramaya University, Ethiopia).

Citation: Temesgen Begna, (2021). “Effect of Striga Species on Sorghum (Sorghum Bicolor L Moench) Production and its Integrated Management Approaches", International Journal of Research Studies in Agricultural Sciences (IJRSAS), 7(7), pp. 10-22 DOI: http://dx.doi.org/10.20431/2454-6224.0707002

Copyright: (c) 2021 Authors. This is an open-access article distributed under the terms of the Creative Commons Attribution License, which permits unrestricted use, distribution, and reproduction in any medium, provided the original author and source are credited. 